\title{
Antineutrophil cytoplasm autoantibodies against bactericidal/permeability-increasing protein in inflammatory bowel disease
}

\author{
R S Walmsley, M H Zhao, M I Hamilton, A Brownlee, P Chapman, R E Pounder, \\ A J Wakefield, C M Lockwood
}

\begin{abstract}
Background-Bactericidal/permeabilityincreasing protein (BPI), a constituent of primary neutrophil granules, is a potent natural antibiotic and an antineutrophil cytoplasm antibody (ANCA) antigen in cases of vasculitis in which the target antigen is neither myeloperoxidase (MPO) nor proteinase-3 (PR3).
\end{abstract}

Aim-To investigate BPI as a possible target antigen for ANCAs in inflammatory bowel disease.

Methods-ANCAs were detected by routine immunofluorescence (IIF) and solid phase enzyme linked immunosorbent assay (ELISA) performed for antibodies to the purified neutrophil granule proteins; MPO, PR3, cathepsin-G, lactoferrin, and BPI in serum samples from 88 patients with inflammatory bowel disease (36 with Crohn's disease, 52 with ulcerative colitis). Thirty patients with bacterial enteritis acted as controls.

Results-Significantly more patients with ulcerative colitis were ANCA positive by IIF $(60 \%)$ than patients with Crohn's disease $(28 \%)$ or infectious enteritis $(23 \%)$ $(\mathbf{p}<0.001)$. IgG anti-BPI antibodies were present in $29 \%$ of patients with ulcerative colitis, $14 \%$ of patients with Crohn's disease, and $23 \%$ of patients with infectious enteritis, occurring in $44 \%$ of those patients with inflammatory bowel disease who were ANCA positive by IIF. Antibodies to other ANCA antigens were rare. The presence of ANCAs was not related to either disease activity or extent; presence of anti-BPI antibodies was significantly related to both a lower serum albumin concentration $(p=0.001)$ and a higher erythrocyte sedimentation rate $(p=0.02)$ in patients with ulcerative colitis, and to colonic involvement in patients with Crohn's disease $(p=0 \cdot 01)$.

Conclusion-BPI is a significant minority target antigen for ANCAs in inflammatory bowel disease that seems related to colonic Crohn's disease and disease activity in ulcerative colitis. Anti-BPI antibodies occur in infectious enteritis.

(Gut 1997; 40: 105-109)

Keywords: antineutrophil cytoplasm autoantibodies, bactericidal/permeability-increasing protein, ulcerative colitis, Crohn's disease.
The idiopathic inflammatory bowel diseases are among the conditions in which a high proportion of patients exhibit the presence of antineutrophil cytoplasm autoantibodies (ANCAs), the target antigens and pathogenetic importance of which have not yet been characterised. ${ }^{1}$ Recently bactericidal/permeability increasing protein (BPI), a constituent of the primary neutrophil granules, has been characterised as an ANCA antigen in vasculitic patients $^{2}$ and patients with cystic fibrosis. ${ }^{3}$ Stoffell et al have found anti-BPI antibodies in $37 \%$ of patients with ulcerative colitis, $23 \%$ of patients with Crohn's disease, and $36 \%$ of patients with primary sclerosing cholangitis ${ }^{4}$; however, no attempt was made to correlate these findings with clinical variables.

BPI has high affinity for Gram negative bacterial lipopolysaccharide (LPS), a potent stimulator of monocyte/macrophages and the endothelium that induces cells to express procoagulant activity, ${ }^{5}$ the leucocyte adhesion molecules E-selectin and ICAM-1, ${ }^{6}$ and proinflammatory cytokines. ${ }^{7}$ It has been reported to protect the endothelium from this activation and injury. ${ }^{8}$

The aim of this study was to investigate the prevalence and possible clinical relevance of BPI antibodies in inflammatory bowel disease, with reference to type, activity, site, and extent of the disease.

\section{Methods}

PATIENTS

Serum samples were collected prospectively from patients with ulcerative colitis $(n=52)$ and Crohn's disease $(n=36)$ under the care of the Royal Free Hospital. Diagnosis of ulcerative colitis was on clinical, radiological, and histological grounds, and that of Crohn's disease on evidence of small bowel involvement or colonic histology showing transmural inflammation or granuloma formation. Serum samples from patients admitted with bacterial enteritis $(n=30)$ acted as controls; blood was taken during the acute phase of their illness and the diagnoses were confirmed by stool or blood cultures.

For patients with inflammatory bowel disease, disease activity was assessed by the Harvey-Bradshaw simple index of Crohn's disease activity, ${ }^{9}$ the simple clinical colitis activity index ${ }^{10}$ an integrated activity index for 
ulcerative colitis calculated from clinical and laboratory data, ${ }^{11}$ and by the relevant haematological and biochemical markers of haemoglobin, packed cell volume, platelet count, $C$ reactive protein, erythrocyte sedimentation rate, and albumin. ${ }^{12}$ Disease site and extent in the patients with inflammatory bowel disease was based on the last endoscopic or radiological investigation before the serum was collected. Serum was stored at $-20^{\circ} \mathrm{C}$ until tested.

Of the 52 cases of ulcerative colitis 17 were men and the median age was $48 \cdot 7$ years (range $21 \cdot 8-82 \cdot 2$ years). Twelve had either total or extensive disease (colitis distal to the hepatic flexure), 24 had left sided or rectosigmoid disease, and 13 had limited proctitis. Three patients had undergone colectomy, one with ileal pouch formation, one with ileorectal anastomosis, and one with terminal ileostomy. Of the 36 patients with Crohn's disease 20 were men and the median age was 37.95 years (range 21.7-82); 16 had colonic involvement.

The median age of the 30 patients with infectious enteritis was 34.4 years (range 20.5-83) and 19 were men. The diagnoses were Campylobacter $s p$ infection in 12, salmonellosis in 11, shigellosis in three (one also having concomitant amoebiasis), enteric fever (Salmonella paratyphi $\mathrm{A}$ ) in three, and one with Clostridium difficile.

\section{ANCA ASSAYS}

\section{Preparation of neutrophil granule proteins}

Cathepsin-G, PR3, and MPO were purified from fresh buffy coat preparations as described previously. ${ }^{13} \mathrm{BPI}$ was purified using techniques described by Zhao et al. ${ }^{2}$ Lactoferrin was purchased commercially (Sigma Chemical Co, Poole, Dorset, UK). Each purified protein was assayed for antigenic purity by enzyme linked immunosorbent assay (ELISA) using antibodies specific to the neutrophil granule proteins MPO, PR3, lactoferrin, cathepsin-G, elastase, and BPI as described. ${ }^{2}$

\section{Solid phase ELISA}

Antigens were diluted in coating buffer (0.05 $\mathrm{M}$ bicarbonate buffer, $\mathrm{pH} \mathrm{9.6)}$ to give a final concentration of $1 \mu \mathrm{g} / \mathrm{ml}$, except for BPI, which was diluted in phosphate buffered saline (PBS) to a final concentration of $0.5 \mu \mathrm{g} / \mathrm{ml}$. All volumes added were $100 \mu 1 /$ well. Microtitre plates (Dynatech Labs Ltd, Billinghurst, England) were coated such that there were two wells containing antigen and two antigen free wells for each sample. Antigen free wells were treated with coating buffer alone for all antigens, except BPI, when PBS alone was used. Incubation was for one hour at $37^{\circ} \mathrm{C}$ for all antigens, except BPI, when plates were left for one hour at room temperature. After washing three times with $0 \cdot 1 \%$ Tween 20 in PBS and drying, serum was added at a dilution of $1: 50$ in $1 \%$ gelatine and $0.1 \%$ Tween 20 in PBS (PBSGT20). Plates were incubated for one hour at $37^{\circ} \mathrm{C}$ followed by repeat washing and addition of alkaline phosphatase conjugated goat antihuman IgG (Stratech Scientific Ltd, Luton, Beds, UK) diluted 1:300 in PBSGT20. Further incubation and washing was followed, finally, by addition of alkaline phosphatase substrate (Sigma Chemicals Ltd, Poole, Dorset, England) diluted to $1 \mathrm{mg} / \mathrm{ml}$ in substrate buffer. Plates were read when the optical density at $405 \mathrm{~nm}$ of positive sample was greater than $1 \cdot 0$. In all ELISAs the positive serum samples were taken as $100 \%$ and the negative samples as $10 \%$ : a sample was positive if activity was greater than $16 \%$ (mean plus $3 \mathrm{SD}$ from 46 normal blood donors). Positive serum samples were chosen as those with the highest specific antigen binding from the samples referred routinely to the laboratory. All the positive reference patients were ANCA positive by IIF and had systemic vasculitis.

Indirect immunofluorescence (IIF)

Indirect immunofluorescence was performed with slight modification from the techniques described by van der Woude et al. ${ }^{14}$ Briefly, serum samples were diluted 1:8 in PBS of which $30 \mu$ l was overlaid onto the alcohol fixed neutrophil cytospin spot on a glass slide. After incubation at room temperature for 40 minutes in a moist chamber, slides were washed gently three times in PBS for a minimum of 25 minutes, then carefully wiped and air dried. Fluorosceine isothiocyanate conjugated rabbit antihuman IgA/G/M $\kappa / \lambda$ (DAKO Ltd, High Wycombe, England; $30 \mu$ liluted 1:20 in PBS) was overlaid onto the neutrophil spots and incubated at room temperature again for 40 minutes in a moist and dark chamber. Washing was repeated keeping the washing chamber covered to exclude light. After drying, slides were stored at $4^{\circ} \mathrm{C}$ until viewed under an ultraviolet light microscope.

All serum samples were coded to ensure that investigations were carried out blind. All positive ELISA results were confirmed by repeat testing, and IIF was read independently by three observers and the consensus view taken. Grading was as either,,$++++/-$, or (the first three categories were taken as being positive) and the perinuclear or cytoplasmic ANCA distribution noted.

\section{STATISTICAL ANALYSES}

Differences in incidence of positive IIF and specific ANCAs between groups were analysed by $\chi^{2}$ test or Fisher's exact test when appropriate. Analysis of differences in disease activity was by Wilcoxon's rank sum test or MannWhitney $U$ test. Haematological and biochemical results were analysed by an unpaired $t$ test assuming unequal variances. Significance was taken as $\mathrm{p}<0.05$.

\section{Results}

Table I summarises the results of the IIF and ELISA assays in each of the three groups. 
TABLE I ANCA by IIF and specific antigen ELISA

\begin{tabular}{llllllc}
\hline & IIF+(total $n)$ & $M P O(n)$ & $P R 3(n)$ & Cathepsin-G $(n)$ & Lactoferrin $(n)$ & $B P I(n)$ \\
\hline Infectious enteritis $(\mathrm{n}=30)$ & $7^{\star}$ & 0 & 1 & $6 \neq 5$ & 2 & 7 \\
Ulcerative colitis $(\mathrm{n}=52)$ & $35 \dagger$ & 1 & 0 & $2 \ddagger$ & 2 & 15 \\
Crohn's disease $(\mathrm{n}=36)$ & $10 \dagger$ & 0 & 1 & 15 & 1 & 5
\end{tabular}

$\mathrm{MPO}=$ myeloperoxidase; $\mathrm{PR} 3=$ proteinase $-3 .{ }^{\star} \mathrm{p}=0.0003$; ulcerative colitis $v$ infectious enteritis. $\mathrm{tp}=0.0006$; ulcerative colitis $v$ Crohn's disease. $\ddagger \mathrm{p}=0.02$; infections enteritis $v$ ulcerative colitis. $\$ \mathrm{p}=0.038$; infectious enteritis $v$ Crohn's disease.

TABLE II ANCA by IIF and anti-BPI ELISA in patients with ulcerative colitis with reference to extent of disease and treatment

\begin{tabular}{lrl}
\hline & $I I F+(n)$ & $B P I+(n)$ \\
\hline Disease extent (no of patients) & & \\
Total/extensive $(\mathrm{n}=12)$ & 8 & 5 \\
Left/rectosigmoid $(\mathrm{n}=25)$ & 17 & 7 \\
Proctitis $(\mathrm{n}=13)$ & 9 & 2 \\
$\quad$ Pouch/ileostomy $(\mathrm{n}=2)$ & 1 & 1 \\
Immunosuppressive therapy: & & \\
$\quad$ Systemic steroids +/- azathioprine $(\mathrm{n}=19)$ & 15 & 7 \\
5ASA/none (n=33) & 20 & 6 \\
\hline
\end{tabular}

ULCERATIVE COLITIS

Sixty per cent (35) of the patients with ulcerative colitis were ANCA positive by IIF; 13 had a clear cytoplasmic pattern, four a clear perinuclear pattern, and 17 an atypical IIF of lesser intensity. Fifteen patients had IgG antiBPI antibodies, three of whom were negative by IIF. The presence of either ANCA by IIF or anti-BPI antibodies was not related to extent of disease (Table II). In the analysis of markers of disease activity (Table III), serum albumin concentrations were significantly lower in the anti-BPI positive group $(p=0.001)$ and erythrocyte sedimentation rates were higher $(p=0 \cdot 02)$. Differences in the simple clinical colitis activity index (in which quiescent disease gives a score of zero), ${ }^{10}$ and the integrated activity index (in which a score $<150$ represents mild disease), ${ }^{11}$ were not significantly different between IIF positive and negative groups, but there was a trend to higher integrated activity scores in the anti-BPI positive patients $(p=0.055)$.

\section{CROHN'S DISEASE}

In Crohn's disease $28 \%$ were ANCA positive by IIF, three showing strong classic cytoplasmic staining, two perinuclear staining, and five had less intense fluorescence. Five patients were anti-BPI positive, three of whom were positive for ANCA by IIF. Tables IV and V summarise the results.

Colonic involvement was associated significantly with the presence of anti-BPI antibodies $(p=0.01$, Fisher's exact test), and although more of those with colonic Crohn's disease were positive for ANCA by IIF this did not reach significance $(p=0 \cdot 28)$. There were no differences between anti-BPI positive and negative groups in any markers of disease activity, including the Harvey-Bradshaw index (in which a score $<3$ is taken as indicating quiescent disease).${ }^{9}$ However, the erythrocyte sedimentation rate for the patients ANCA positive by IIF were significantly lower than in the negative group $(p=0.003)$.

\section{INFECTIOUS ENTERITIS}

In the infectious enteritis group, seven were ANCA positive by IIF; two with clear cytoplasmic staining, five with borderline fluorescence. Of the seven with anti-BPI antibodies four were ANCA negative by IIF, two had shigellosis, two salmonellosis, one Clostridium difficile enteritis, one had enteric fever, and one Campylobacter infection.

\section{Discussion}

These data confirm the high prevalence of ANCAs in ulcerative colitis and an association of ANCAs with colonic Crohn's disease, as described previously. ${ }^{15-17}$ We have also shown qualitatively that PR3, MPO, cathepsin-G, and lactoferrin together constitute only $21 \%$ of the target ANCA antigens. A novel finding is that in inflammatory bowel disease BPI is also a minority ANCA antigen, and that anti-BPI antibodies are present in $44 \%$ of patients ANCA positive by IIF. The vulnerability of the antigenicity of BPI to destruction by serine proteases $^{18}$ explains why there were some patients with anti-BPI antibodies who had negative ANCA by IIF. In the infectious enteritis group cathepsin-G was the major ANCA target antigen. In Wegener's granulomatosis ANCA immunoreactivity correlates positively with disease activity ${ }^{19}$ but we have been unable to show any association with a range of markers of disease activity in inflammatory bowel disease, in agreement with most other publications on the subject. ${ }^{15172021}$ Nor was there any relation with use of steroids, as has been suggested. ${ }^{15} 22$ The presence of antiBPI antibodies in this study is associated significantly with colonic involvement in Crohn's disease, and with disease activity as measured by both serum albumin and erythrocyte

TABLE III Markers of disease activity in patients with ulcerative colitis

\begin{tabular}{|c|c|c|c|c|c|c|c|c|}
\hline & & $H b(g / d l)$ & Plts $\left(\times 10^{9}\right)$ & $P C V(M)$ & $E S R(\mathrm{~mm} / \mathrm{hr})$ & $\begin{array}{l}\text { Serum } \\
\text { albumin }(g /)\end{array}$ & $\begin{array}{l}\text { Integrated } \\
\text { activity score }\end{array}$ & $\begin{array}{l}\text { Simple clinical } \\
\text { activity score }\end{array}$ \\
\hline $\begin{array}{l}\text { ANCA by IIF } \\
\text { ANCA by IIF } \\
\text { BPI } \\
\text { BPI }\end{array}$ & $\begin{array}{l}+(n=35) \\
-(n=17) \\
+(n=15) \\
-(n=37)\end{array}$ & $\begin{array}{l}13.0(1.64) \\
13.2(2 \cdot 18) \\
12.6(1.76) \\
13.2(1.83)\end{array}$ & $\begin{array}{l}340(114) \\
318(114) \\
364 \cdot 4(120) \\
319 \cdot 6(124)\end{array}$ & $\begin{array}{l}0.38(0.047) \\
0.39(0.058) \\
0.375(0.053) \\
0.388(0.049)\end{array}$ & $\begin{array}{l}28 \cdot 75(23 \cdot 9) \\
18 \cdot 6(13 \cdot 6) \\
40 \cdot 7(30)^{\star} \\
19 \cdot 2(13)^{\star}\end{array}$ & $\begin{array}{l}43(6) \\
43 \cdot 8(6) \\
39(7 \cdot 67)^{\star \star} \\
45 \cdot 1(4 \cdot 01)^{\star \star}\end{array}$ & $\begin{array}{l}135(53) \\
124(51) \\
158 \cdot 7(58 \cdot 7) \\
119 \cdot 7(44 \cdot 8)\end{array}$ & $\begin{array}{l}4 \cdot 1(2 \cdot 6) \\
3 \cdot 7(3 \cdot 0) \\
4 \cdot 8(2 \cdot 51) \\
3 \cdot 7(2 \cdot 78)\end{array}$ \\
\hline
\end{tabular}

Results are given as means $(\mathrm{SD})$. $\mathrm{Hb}=$ haemoglobin; Plts=platelets; $\mathrm{ESR}=$ erythrocyte sedimentation rate; $\mathrm{PCV}=$ packed cell volume ${ }^{\star} \mathrm{p}<0.02 ;{ }^{\star} \mathrm{p}<0.0013$. 
TABLE IV ANCA by IIF and anti-BPI ELISA in patients with Crohn's disease with reference to extent of diesease and treatment

\begin{tabular}{lll}
\hline & \multicolumn{1}{l}{$I I F+(n)$} & $B P I+(n)$ \\
\hline Disease site: & & \\
$\quad$ No colonic involvement $(n=20)$ & 4 & $0^{\star}$ \\
$\quad$ Colonic involvement $(n=16)$ & 6 & $5^{\star}$ \\
Immunosuppressive therapy: & & \\
$\quad$ Systemic steroids $+/$ - azathioprine $(\mathrm{n}=20)$ & 6 & 4 \\
None/5ASA $(\mathrm{n}=16)$ & 4 & 1 \\
\hline${ }^{*} \mathrm{p}=0.01$. &
\end{tabular}

sedimentation rate in ulcerative colitis. There was also a trend for higher disease activity scores in those patients with ulcerative colitis and anti-BPI antibodies. It should be noted that serum samples and disease activity assessments of the patients with inflammatory bowel disease were collected mainly from outpatients, only eight having severe enough disease to warrant inpatient treatment.

We found a relatively high prevalence of antiBPI antibodies in patients with infectious bacterial enteritis, of whom $23 \%$ were positive. This compares with the routine positive rate of $11 \%$ in serum samples referred for ANCA analysis to this laboratory. ${ }^{2}$

BPI is one of the most potent natural antibiotics produced by neutrophils. ${ }^{23}$ It is a highly cationic, membrane associated protein found in cells of myeloid lineage, and has high affinity for the lipopolysaccharide cell wall component of Gram negative bacteria (endotoxin). It has been shown in vitro to inhibit lipopolysaccharide stimulated pro-inflammatory cytokine release from neutrophils and whole blood, ${ }^{24}{ }^{25}$ as well as protecting human endothelial cells against endotoxin induced IL-6 production and injury, as indicated by lactose dehydrogenase release. ${ }^{8}$

Complexes of the peptidoglycanpolysaccharide component of the cell walls of intestinal microflora, ${ }^{26}$ as well as specific bacterial antigens including Escherichia coli and Listeria monocytogenes, have been shown by immunohistochemistry to be present within the bowel wall of patients with Crohn's disease.$^{27}$ Systemic endotoxaemia, as measured by the limulus amoebocyte lysate assay, has been found to correlate both with disease activity and extent in inflammatory bowel disease. ${ }^{28}$ Colonic mucosal concentrations of BPI have been reported to be higher in both ulcerative colitis and Crohn's disease compared with controls, ${ }^{29}$ possibly reflecting a host attempt to attenuate the proinflammatory actions of lipopolysaccharide. Weiss $e t$ al have shown that the bactericidal activity of acid extracts of neutrophils on Salmonella typhi- murium can be blocked by serum containing goat anti-BPI $\mathrm{IgG}^{30}$ and in cystic fibrosis, a condition in which recurrent infection and colonisation with Gram negative organisms is common, $91 \%$ of patients had anti-BPI IgG antibodies. ${ }^{3}$ This study would also suggest that anti-BPI ANCA may occur as a secondary response to acute or chonic Gram negative bacterial colonisation. Further work is required to determine whether these antibodies act to abrogate the bactericidal activity of BPI, or lessen its protective effect against the inflammatory action of bacterial endotoxin on neutrophils, monocytes, and endothelium.

In summary, a significant minority of ANCAs in inflammatory bowel disease are directed against the naturally occurring antibiotic bactericidal/permeability increasing protein. Their biological relevance will be considered in further studies.

1 Hagen EC, Ballieux EPB, van Es LA, Daha MR, van der Woude FJ. Antineutrophil cytoplasmic antibodies: a review of the antigens involved, the assays, and the clinical and possible pathogenetic consequences. Blood 1993; 81: and possible

2 Zhao MH, Jones SJ, Lockwood CM. Bactericidal permeability-increasing protein (BPI) is an important antigen for anti-neutrophil cytoplasmic autoantibodies (ANCA) in vasculitis. Clin Exp Immunol 1995; 99: 49-56.

3 Zhao MH, Jayne DRW, Arilles LG, Culley F, Hodson ME Lockwood CM. Autoantibodies against bactericidal permeability-increasing protein in patients with cystic fibrosis. QfM 1996; 89: 259-65.

4 Stoffell MP, Csernok E, Herzberg C, Johnston T, Carroll SF, Gross WL. Anti-neutrophil cytoplasmic antibodies (ANCA) directed against bactericidal/permeability (ANCA) directed against bactericidal/permeability increasing protein (BPI): a new seromarker for inflam-
matory bowel disease and associated disorders. Clin Exp Immunol 1996; 104: 54-9.

5 Stern DM, Bank I, Nowroth PP, Cassimeris J, Kisiel W, Fenton JW, et al. Self-regulation of the procoagulant events of the endothelial cell. $f$ Exp Med 1985; 162 1223-5.

6 Dustin ML, Springer TA, Lymphocyte function associated antigen-1 (LFA-1) interaction with intercellular adhesion molecule-1 (ICAM-1) is one of at least three mechanisms for lymphocyte adhesion to cultured endothelial cells. $\mathcal{F}$ Cell Biol 1988; 107: 321-31.

7 Jirik FR, Pober TJ, Hirano T, Kishimoto T, Loskutoff DJ, Carson DA, et al. Bacterial lipopolysaccharide and inflammatory mediators augment IL-6 secretion by human matory mediators augment IL-6 secretion

8 Arditi M, Zhou J, Huang SH, Luckett PM, Marra MN, Kim KS. Bactericidal/permeability-increasing protein protects vascular endothelial cells from lipopoly saccharide-induced activation and injury. Infect Immun 1994; 62: 3930-6.

9 Harvey RF, Bradshaw JM. A simple index of Crohn's disease activity. Lancet 1980; i: 514.

10 Walmsley RS, Ayres RCS, Allan RN. A really simple colitis activity index [abstract]. Gut 1994; 35 (suppl 5): S29.

11 Seo $M$, Okada $M$, Yao $T$, Ueki $M$, Arim S, Okumara $M$. An index of disease activity in Ulcerative Colitis. $A m \mathcal{F}$ Gastroenterol 1992; 87: 971-6.

12 Cooke WT, Prior P. Determining disease activity in inflammatory bowel disease. $\mathcal{f}$ Clin Gastroenterol 1984; 6: matory

13 Kao RC, Wehner NG, Skubitz KM, Gray BH, Hoidal JR. Proteinase 3: a distinct human polymorphonuclear leukocyte proteinase that produces emphysema in hamsters. $f$ Clin Invest 1988; 82: 1963-73.

14 Woude FJV, Rasmussen N, Lobatto S, Wiik A, Permin H, Es LAV, et al. Autoantibodies to neutrophils and monocytes: a new tool for diagnosis and marker of disease activity in Wegner's granulomatosis. Lancet 1985; 2: 425-9.

TABLE V Markers of disease activity in patients with Crohn's disease

\begin{tabular}{lllllllll}
\hline & & & & & $\begin{array}{l}\text { CRP } \\
(\mathrm{mg} / \mathrm{l})\end{array}$ & $\begin{array}{l}\text { ESR } \\
(\mathrm{mm} / \mathrm{hr})\end{array}$ & $\begin{array}{l}\text { Serum } \\
\text { albumin }(\mathrm{g} / \mathrm{l})\end{array}$ & $\begin{array}{l}\text { Harvey-Bradshaw } \\
\text { index }\end{array}$ \\
\hline ANCA by IIF & $+(\mathrm{n}=10)$ & $13 \cdot 09(1 \cdot 3)$ & $311(124)$ & $0.39(0 \cdot 031)$ & $1 \cdot 83(1 \cdot 8)$ & $10 \cdot 7(6 \cdot 8)^{\star}$ & $44 \cdot 1(4 \cdot 3)$ & $1 \cdot 7(1 \cdot 7)$ \\
ANCA by IIF & $-(\mathrm{n}=26)$ & $13 \cdot 2(2 \cdot 0)$ & $313(98)$ & $0.391(0.055)$ & $3 \cdot 2(1 \cdot 9)$ & $22(14)^{\star}$ & $41 \cdot 7(4 \cdot 6)$ & $5 \cdot 0(4 \cdot 4)$ \\
Anti-BPI & $+(\mathrm{n}=5)$ & $12 \cdot 8(0 \cdot 9)$ & $364(161)$ & $0.39(0 \cdot 027)$ & $3 \cdot 4(1 \cdot 7)$ & $22(17)$ & $42 \cdot 6(5 \cdot 2)$ & $3 \cdot 0(2 \cdot 3)$ \\
Anti-BPI & $-(\mathrm{n}=31)$ & $13 \cdot 2(1 \cdot 9)$ & $304(92)$ & $0.394(0.052)$ & $2 \cdot 9(2 \cdot 1)$ & $18 \cdot 3(13)$ & $42(4 \cdot 5)$ & $4 \cdot 4(4 \cdot 3)$ \\
\hline
\end{tabular}


15 Cambridge G, Rampton DS, Stevens TR, McCarthy DA, Kamm M, Leaker B. Anti-neutrophil antibodies in inflammatory bowel disease: prevalence and diagnostic role. Gut 1992; 33: 668-74.

16 Duerr RH, Targan SR, Landers CJ, Sutherland LR, Shanahan F. Anti-neutrophil cytoplasmic antibodies on ulcerative colitis. Gastroenterology 1991; 100: 1590-6.

17 Saxon A, Shanahan F, Landers C, Ganz T, Targan S. A distinct subset of anti-neutrophils cytoplasmic antibodies is associated with inflammatory bowel disease. 7 Allergy Clin Immunol 1990; 86: 202-10.

18 Jones SJ, Zhao MH, Elliott JD, Lockwood CM. The antigenicity of bactericidal/permeability-increasing protein (BPI) is threatened by serine proteases. Clin Exp Immunol 1995; 101 (suppl 1): 36.

19 Jayne D, Heaton A, Brownlee A, Evans DB, Lockwood CM. Sequential antineutrophil cytoplasmic antibody titres in the management of systemic vasculitis. Nephrol Dial Transplant 1990; 5: 309-10.

20 Seibold F, Weber P, Klein R, Berg PA, Wiedmann KH. Clinical significance of antibodies against neutrophils in
patients with inflammatory bowel disease and primary patients with inflammatory bowel disease a

21 Pool MO, Ellerbroek PM, Ridwan BU, Blomberg BME, Pena AS, Dolman KM, et al. Serum antineutrophil cytoplasmic autoantibodies in inflammatory bowel disease are mainly associated with ulcerative colitis. A correlation study between perinuclear antineutrophil cytoplasmic autoantibodies and clinical parameters, medical and surgical treatment. Gut 1993; 34: 46-50.

22 Roth M, Rump JA, Gross WL, Peter HH, Gerok W, Scholmerich J. A new type of anti-neutrophil antibodies in sera from patients with ulcerative colitis but not Crohn's disease. Gastroenterology 1991; 100: A244.
23 Levy O, Ooi CE, Elsbach P, Doerfler ME, Lehrer RI, Weiss J. Antibacterial proteins of granulocytes differ in interaction increasing protein, p15s, and defensins. f Immunol 1995; increasing prot $5403-10$.

24 Ooi CE, Weiss J, Doerflr E, Elsbach P. Endotoxinneutralising properties of the $25 \mathrm{kD} \mathrm{N}$-terminal fragment and the newly isolated $30 \mathrm{kD}$ C-terminal fragment of the $55-60 \mathrm{kD}$ bactericidal/permeability increasing protein of human neutrophils. f Exp Med 1991; 174: 649-55.

25 Desch CE, Kovach NL, Present W, Broyles C, Harlan JM. Production of human tumour necrosis factor from whole blood ex vivo. Lymphokine Research 1989; 8: 141-5.

26 Klasen IS, Melief MJ, van Halteren AGS, Schouten WR, van Blankenstein M, Hoke G, et al. The Presence of peptidoglycan-polysaccharide complexes in the bowel wall and the cellular responses to these complexes in Crohn's disease. Clin Immunol Immunopathol 1994; 71: 303-8.

27 Liu Y, Van Kruningen J, West AB, Cartun RW, Cortot A, Colombel J. Immunocytochemical evidence of Listeria, Escherichia coli and Streptococcus antigens in Crohn's disease. Gastroenterology 1995; 108: 1396-404.

28 Gardiner KR, Halliday MI, Barclay GR, Milne L, Brown D, Stephens $S$, et al. Significance of systemic endotoxaemia in inflammatory bowel disease. Gut 1995; 36: 897-901.

29 Monajemi H, Meenan J, Lamping R, Obramov O, Radema SA, Trown PW, et al. Inflammatory bowel disease is associated with raised mucosal levels of bactericidal/permeability increasing protein. Gastroenterology $199 ; 110: 733$ -

30 Weiss J, Victor M, Stendhal O, Elsbach P. Killing of gramnegative bacteria by polymorphonuclear leukocytes. Role of an $\mathrm{O}_{\text {-independent bactericidal system. } \mathfrak{f} \text { Clin Invest }}$ 1982; 69: 959-70. 